\title{
逆転磁場ピンチによるプラズマ閉じ込め
}

\author{
(東京大学理学部) 宮 本 健 郎
}

逆磁場ピソチ(RFP)の研究は核融合研究の樶も早い時期から始められていたが,トカマクT3の画期

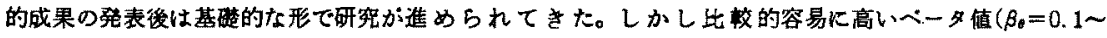
0.15)が得られ，実駼芰置がコンバクトであり，電磁流体力学的安定性の研究に適したブラズマが作られ

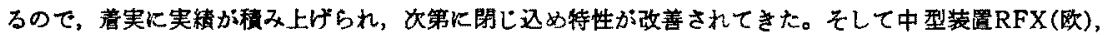

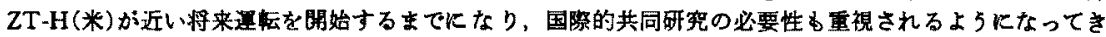
た。この機会にRFP研究の現状を镸り返り、その将来を展望する。

\section{I. 序論}

巡転磁場ピンチ(RFP; Reversed Field Pinch)の研 究は核蚰合研究の最す早い時期から始められだ(1)。 ーラス・ブラズマ中に弱いトロイダル磁場を加えプ ラズマ中に䉓流を立ら上げてZピンチさせる。初期 における代表的装置は英国 Harwell 研究所における ZETAである。ピンチ・ブラズマの電磁流体力学的 (MHD)不安定性の研究が行われ，放䉓初期化不安定 であっても MHD和が起って安定で静かな状態 (quiescent phase)K移行することがZETAにおいて観 測され, 1968年にソ連のNovosibirskで開かれた国際原 子力機関(IAEA)主催の国柡会淁(2) で発表された。

この静かな状態沈おける磁場配位が，いわゆる逆転 磁場ピンチの配位である。トロイダル磁埸 $B_{2}(r)$ とポ ロイタル磁 $B_{\theta}(r)$ (プラズ、電流によって生じる $\theta$ 方向の磁場)のブラズマ小半径 $r$ 方向の空間分布を画 くと第1图のようになっている。第1图からかかるよ 5 飞, $B_{\varepsilon}(r)$ と $B_{\theta}(r)$ の大きさは同じ程度であり, $B_{2}(r)$ は中心から外側に向かって减少し，ぜとなり，周辺 部では向きが逆転している。

RFPの磁場配位はトカマクと同様，回転対称であ り，粒子の軌道損失が小さいという利点を共有してい るが，B, $(r), B_{\theta}(r) か ゙$ 同じ程度の大きさであること， $B_{s}(r)$ の空間分布が外側で逆転しているといら点で, ト カマク配位と著しく異なっている。このことは，磁揚 の拱れ(シフ)が大きく(第 2 图)，此較的高いベータ值 （ブラズマ压力の磁場仕力に対する比） $\beta=10 \sim 15 \%$ の ブラズマをMHD安定K閉じ込めることができる。ま
た安全係数 $q(r)=\frac{r}{R} \cdot \frac{B_{3}(r)}{B_{\theta}(r)}$ 怔1よりかなり小さい $(q(0)=a /(R \theta), \theta \sim 1.6 ; a, R$ はプラズ、の小半径拉 上び大半径)。したがって，クルスカル・シャフラノフ 制限を超えてプラズマ電流を大きく流すことができる ので(トカマクの場合は $q(a)>2 \sim 3)$ ，もしエネルギー 閉し込め時間が良ければ，オーム加熱のみで妒心温度 までブラズマを加熱できる可能性をるっている。

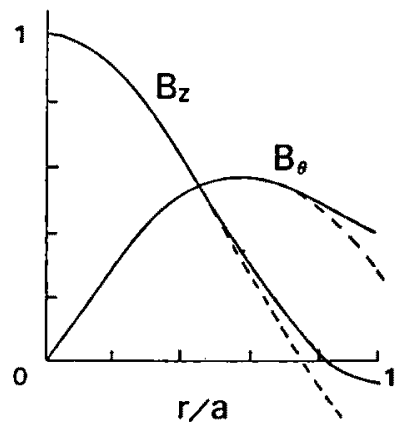

点線はべッセル関数モデル(BFM)で， 実線は変形されたベッセル留数モデル (MBFM)。

第 1 园 RFPブラズマ中のトロイダル

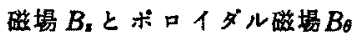
の半径 $r$ 方向の空間分布

しかし，ZETAの静かな状態の発見が発表された同 じ会識で、トカマクT-3の画期的成果 $\left(T_{a} \approx 1 \mathrm{keV}, \simeq\right.$ ネルギー閉し这め時間 $\tau_{\boldsymbol{I}} \sim$ 数 $\mathrm{ms}$ ) に注目が集まり， ZETAは閉鎖の運命をたどった。それはトカマクの閉

Confinement of Reversed Field Pinch Plasma: Kenro Miyamoto.

(1990年8月21日 受理) 

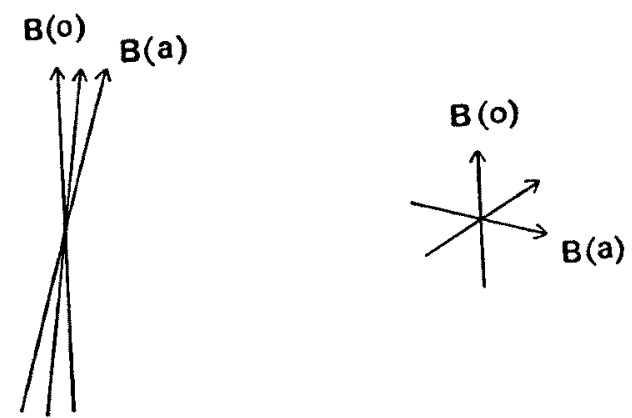

第 2 园トカマク(右図)とRFP(左図)の 場合の磁気シフの粎子

じ込め特性が優れていたためである。 その後，RFPは小規模な形で研究が続けられ，ベー タ值の高いブラズマが容易に作れること，装直がコン ハクトで建設費が少ないこと(同じ $B_{\theta}$ たはプラズ、 電流 $I_{p}$ K対して必要なトロイダル磁場 $B_{x}(a)$ はトカー クに比べて 1 桁以下であるの利点を生かしながら, 次 第に改良が加えられ，閉じ込め特性就よびプラズマ・パ ラメータ向上してきた(3)。

そしてEC(欧)ではRFX(パドバ)，米国ではZT-H (口スアラモス)と，より大型の䁂(トカマクの基慗 では中型によるブロジェクト研究が進行中である。 このよらな状沉下でこのほと卭A(International Energy Agency) 全下で日米欧逝転陪場ピンチ国際協力 協定が調印されたことは，これからのRFP研究の発展 にとって大变意義深いことである。この機会にRFP研 究の現状を振り返り，将来の展望を試みる。

\section{RFP 装 贯}

RFP装置の概念図を，空心変流器の例について第 3 因火示す。磁昜コイル系はトカマクと同様でトロイ ダル磁場コイル,オーム加熱コイル，平衡用垂直磁場 コ イルからなる。ただ，同じ程度のプラズマ電流に対 して必要なトロイダル磁場はトカマクの場合に比へて 1 桁以上小さい。薄肉ステンレス鋼あるいはインコネ ル製の真空容器の周りに，MHD安定性確保のため尊 体シェルがある。逆転のための可変トロイダル磁場就 よびオーム加熱のためのトロイダル電埸がブラズマに

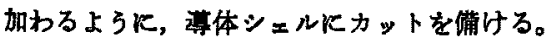

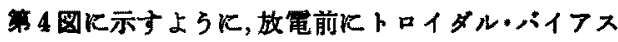
磁場を加え， ｍs 程度の時定数でブラズ、奄流を立ら 上げると同時に，外部トロイダル磁場を逆枟させる。 $B_{4}(r) \sim B_{0}(r)$ であるため，磁力線のトロイダル方向の

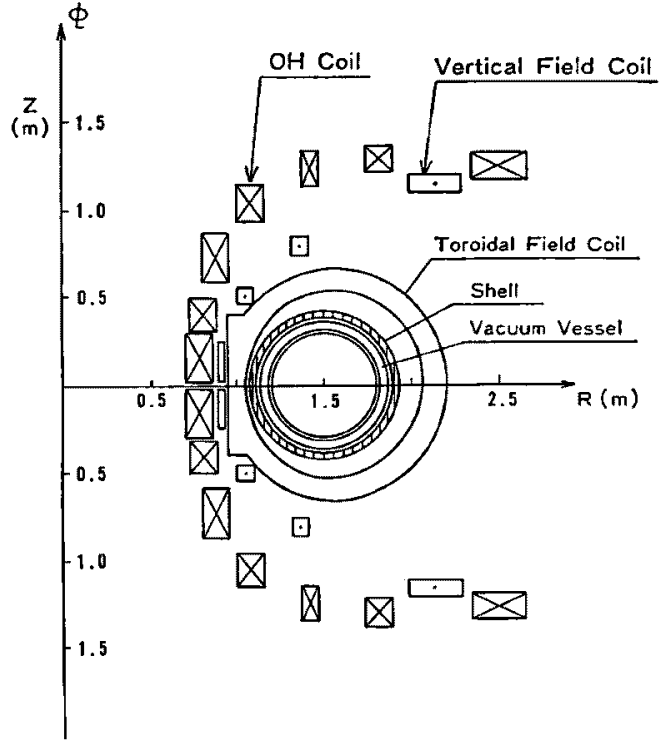

第 3 図 RFP装固の概念図(空心変流器の場合)

ピッチ長が短く，そのため装置の回転対称性の要求精 度はトカマクょりきびしい。またフフラズマのMHD安 定性の確保のために, ブラズマに接近して導体シニル を濞く必要がある(提抗性シェルでは不充分)。

\section{RFPの MHD啰和}

ブラズマ放電の初期状態にあまり体存しないで, MHD安定なRFP配位が現れてくるといら実験事実の 発見後 6 年目の1974年に, J.B. Taylor ${ }^{(4)}$ がその理論的 説明を行なった。ある磁気面に囲まれた領域に扰ける 磁場 $\boldsymbol{B}$ と，そのペクトル・ポテンシャルAのスカラー 積の積分

$$
\boldsymbol{K} \equiv \int \boldsymbol{A} \cdot \boldsymbol{B} d V
$$

を導入した。これを磁気へリシティーといら。スカラ 一・ポテンシャルをめとすると，

$$
\boldsymbol{E}=-\nabla \phi-\frac{\partial \boldsymbol{A}}{\partial t}, \quad \boldsymbol{B}=\nabla \times \boldsymbol{A}
$$

であり、マックスウェルの式から

$$
\begin{aligned}
\frac{\partial}{\partial t}(\boldsymbol{A} \cdot \boldsymbol{B})= & \frac{\partial \boldsymbol{A}}{\partial t} \cdot \boldsymbol{B}+\boldsymbol{A} \cdot \frac{\partial \boldsymbol{B}}{\partial t} \\
= & (-\boldsymbol{E}-\nabla \phi) \boldsymbol{B}-\boldsymbol{A} \cdot(\boldsymbol{\nabla} \times \boldsymbol{E}) \\
= & -(\boldsymbol{E} \cdot \boldsymbol{B})-\nabla \cdot(\phi \boldsymbol{B})+\nabla \cdot(\boldsymbol{A} \times \boldsymbol{E}) \\
& -\boldsymbol{E} \cdot(\boldsymbol{\nabla} \times \boldsymbol{A}) \\
= & -2(\boldsymbol{E} \cdot \boldsymbol{B})-\nabla \cdot(\phi \boldsymbol{B}+\boldsymbol{E} \times \boldsymbol{A})
\end{aligned}
$$

となる。したがって 


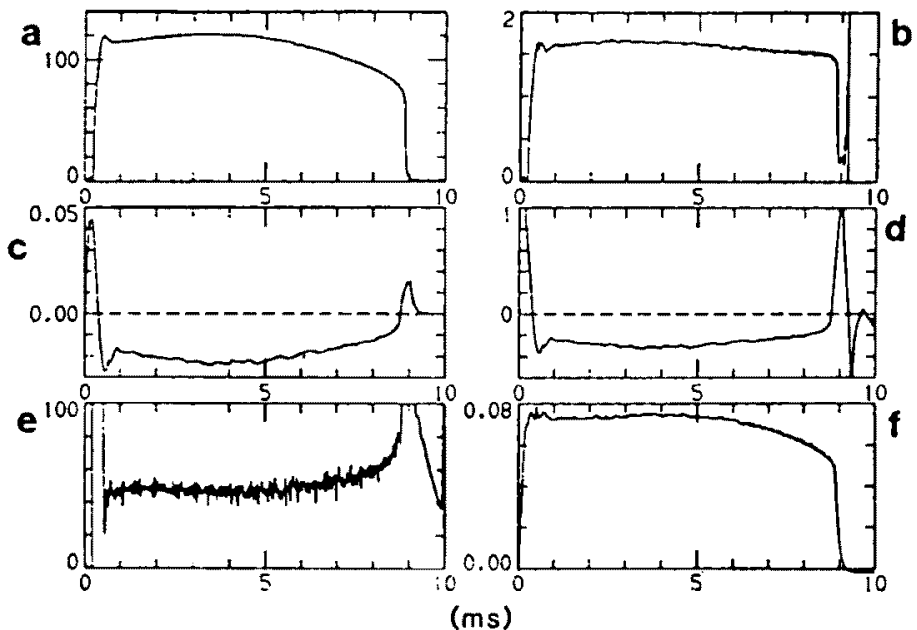

(a) プラズマ電流 (kA)，(b) $\theta \equiv B_{0}(a) /\left\langle B_{s}\right\rangle$

(c) 放電管壁におけるトロイダル磁場 $B_{x}(a)(\mathrm{T})$

(d) $F \equiv B_{z}(a) /\left\langle B_{z}\right\rangle, \quad$ (e) トロイダル・ループ電代(V)

(f) 平均トロイダル磁場 $\left\langle B_{z}\right\rangle(\mathrm{T})$

第 4 图 ZT-40 Mの長時間故電の時間的变化

$$
\begin{aligned}
\frac{\partial K}{\partial t} & =\int_{V} \frac{\partial}{\partial t}(\boldsymbol{A} \cdot \boldsymbol{B}) d V \\
& =-2 \int(\boldsymbol{E} \cdot \boldsymbol{B}) d V=-2 \int \eta(\boldsymbol{j} \cdot \boldsymbol{B}) d V
\end{aligned}
$$

となる $(\eta \boldsymbol{j}=\boldsymbol{E}+\boldsymbol{W} \times \boldsymbol{B})$ 。比抵抗率 $\eta=0$ の場合，磁気 ヘリシティーは保存される。すしプラズマが小さな抵 抗を持つ場合には，磁力線の再結合 (reconnection) に よって磁力線のトポロジーが変わり，局所的には磁気 ヘリシティーは变化する。しかし，Taylorは，その昜 合でる，ブラズマの全領域の $K$ 積分 $K_{T}$ 哚存される と考えた(変化するとしてる磁場搪散時間程度のゆ。 くりした変化をする)。このような拘束条件の下で硢 気エネルギーを最小炡する磁場配位は，変分法より

$$
\begin{aligned}
& 8 K_{r}=2 \int_{V_{T}} B \cdot \delta A d V=0 \\
& \frac{1}{2 \mu_{0}} \delta \int_{V \boldsymbol{r}}(\boldsymbol{B} \cdot \boldsymbol{B}) d V \\
& =\frac{1}{\mu_{0}} \int \boldsymbol{B} \cdot \delta(\nabla \times A) d V \\
& =\frac{1}{\mu_{0}}(\nabla \times \boldsymbol{B}) \cdot 8 \boldsymbol{A} d V=0
\end{aligned}
$$

そして

$$
\nabla \times B-\lambda B=0
$$

たたし， $\lambda$ : 定数

を満たす必要がある。この方程式の回転対称な解は

$$
\begin{aligned}
& B_{r}=0 \\
& B_{\theta}(r)=B_{0} J_{1}(\lambda r)
\end{aligned}
$$

$$
B_{a}(r)=B_{0} J_{0}(\lambda r)
$$

であり、この解をベッセル関数モデル(BFM)という。 これを図示したのが，第1图の点線である。央験で観 測される結果恃，フラズマ中心部ではほぼBFMモデ ルの理論值に等しいが，周辺ではややずれる。(2)式

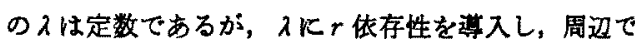
せロとするよらにして得られる(2)式の解が変形され たベッセル関数モデル(MBFM)である。㬰呀結果は MBFMKよく一致する。ピンチ・パラメータ日および 逆転比 $F$ を次のよらに定義する。

$$
\theta \equiv \frac{B_{\theta}(a)}{\left\langle B_{\mathfrak{v}}\right\rangle}, \quad F \equiv \frac{B_{\mathbf{s}}(a)}{\left\langle B_{\mathrm{s}}\right\rangle}
$$

ただし〈结〉:トロイダル磁場のブラズ、断面 平均值

BFMの場合, $\theta=\frac{\lambda a}{2}, F \equiv \frac{\theta J_{0}(2 \theta)}{J_{1}(2 \theta)}$ となる。BFM の $F-\theta$ 曲線を第 5 図(点線)に示す。また実験值を点 で表わす。

\section{MHD楥和の牙的恖程}

ブラズマの有限抵抗を考虑すると，RFP磁垉配位 古典磁揚拉散時間 $\tau_{0 t}=\mu_{0} a^{2} / \eta$ ( $\eta$ : 比抵抗事)の程度し か保持されないはずである。しかし ZT40M の実検(5) Кよれば, $\tau_{e l} の 3$ 倍程度の $9 \mathrm{~ms}$ 以上の放電が実現し

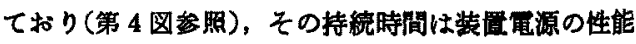

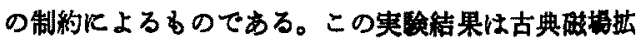




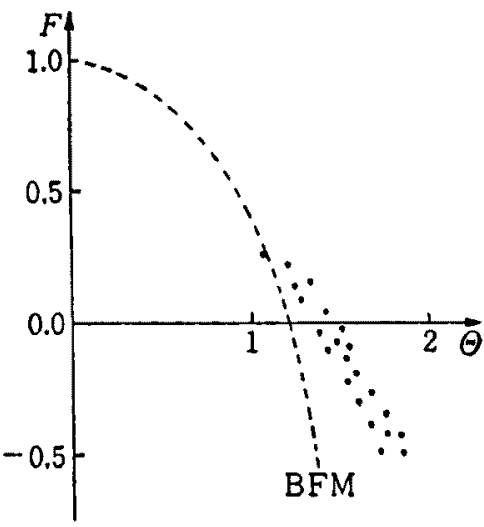

点楾はベッセル溥数モデル(BFM)の場合， 点実祘データを示す。

表 5 图 $F-\Theta$ 曲線

散で失われるトロイダル磁束を補 5再生機構があるこ とを示す明確な証左である。Taylorの理論はMHD緩 和によってたどりつく状態について説明を与えたが， その動的過程，束再生機構については新たな研究が 必要であった。摇動がある場合，オームの法則

$$
\eta j=E+v \times B
$$

の各量を時間平均量 $\langle\boldsymbol{B}\rangle$ と播動項 $\tilde{B}$ 等に分け，時間平 均をとると，

$$
\langle\eta \boldsymbol{j}\rangle_{t}=\langle\boldsymbol{E}\rangle_{t}+\langle\boldsymbol{v}\rangle_{t} \times\langle\boldsymbol{B}\rangle_{t}+\langle\tilde{\boldsymbol{v}} \times \tilde{\boldsymbol{B}}\rangle_{t}
$$

となり，播動項 $\langle\tilde{\boldsymbol{v}} \times \tilde{\boldsymbol{B}}\rangle$ 、が新しくつけ加わる。いま集

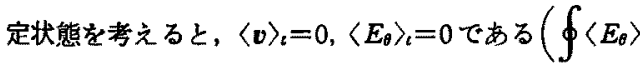

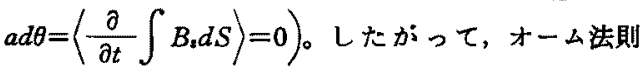
$の \theta$ 成分をとると

$$
\left\langle\eta j_{\theta}\right\rangle_{t}=\left\langle\tilde{v}_{z} \tilde{B}_{r}-\tilde{v}_{r} \tilde{B}_{z}\right\rangle_{l}
$$

となる。すなわち、トロイダル磁束を保つための電流 $j_{\theta}$ を保持しているのは，摇動による実效的電場(ダイ ナモ效果)であることがわかる。この摇動は最も不安 定になり易い $m=1$ (ポロイダルモード数)のキンク不 安定性であることが，理諭的にす，実験的にす確めら れている。第 6 图に示すように，キンク不安定性が起 こるとソレノイド效果でボロイダル磁場が，プラズマ 周边で負のトロイダル磁場成分を発生させ，中心部で 正のトロイダル磁場成分を発生させることがかかる。 そして $m=1$ キンク不安定性によって駆動された磁力 線再結合によってトロイダル磁束が再生されること が, 計算機シ・゙ニレーションによって示されだ(6)。

オーム加熱のために電压を印加していると，電流分 布が急骖化して， $m=1$ キンク不安定性が成長し，非線

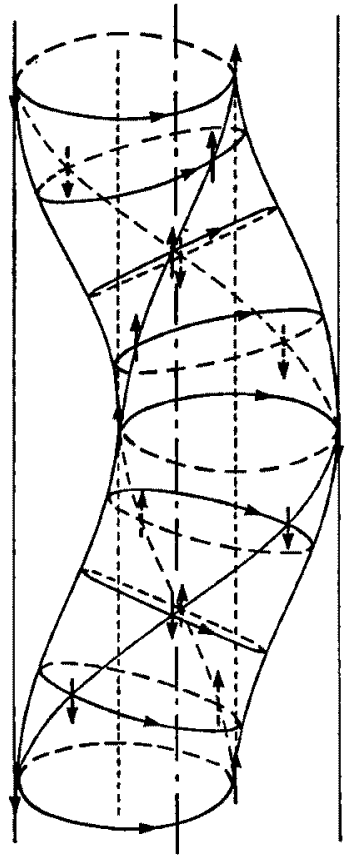

この場合ポロイダル磁場が傾いて，トロイダル磁場 の目の成分がキンクしたプラズ、外側領域に現れる。

第 6 图キンクしたブラズマ

形相互作用に基つくと思われる $m=0 の \mathrm{MHD}$ 緩和現象 が起り，電流分布が平坦化する。としてまた同じ過程 を繰り返えすことが，実験的にる観測された䘞 (10)。 た導体シェルの代わりに抵抗性シェルをおくと,MHD 摇動が大幅に增えることが示された(11)。

V.RFPの閉じ込め比例則

$$
\begin{aligned}
& \text { オーム加熱時に和けるエネルギー・シランスの式は } \\
& \frac{(3 / 2)\left\langle n_{e}\left(\mathcal{T}_{e}+T_{l}\right)\right\rangle_{V} 2 \pi R \pi a^{2}}{\tau_{E}}=V_{x} I_{p} \\
& \text { ここで， } \tau_{B} ; \text { エネルギ一閉じ込め時間 } \\
& V_{\mathbf{s}}: \text { ループ電圧 } \\
& \langle\rangle_{\boldsymbol{r}} \text { : 体積平均 }
\end{aligned}
$$

で与えられる。ポロイダルベータ值阳を

$$
\beta_{\theta}=\frac{\left\langle n_{e}\left\langle T_{\theta}+T_{t}\right)\right\rangle_{V}}{\left(B_{\theta}{ }^{2}(a) / 2 \mu_{0}\right)}=\frac{8 \pi^{2} a^{2}\left\langle n_{e}\left(T_{e}+T_{t}\right)\right\rangle_{r}}{\mu_{0} I_{t}^{2}}
$$

を用いると

$$
\tau_{E}=\frac{3 \mu_{0} R}{8} \beta_{\theta} \frac{I_{p}}{V_{s}}
$$

に邆元される。RFPブラズマにルーブ電压V、を加える ために，その周りの導体シェルにカットを設けると， 磁気へリシティー $K_{T}$ の時間变化は（1)式の抵抗損失 
項の外にシェル・カットからの入力項が加わり

$$
\frac{\partial K_{T}}{\partial t}=-2 \int_{V} \eta(\boldsymbol{j} \cdot \boldsymbol{B}) d V+2 V_{s} \Phi_{*}
$$

ただし， $\langle B,\rangle_{V} \pi a^{2}$

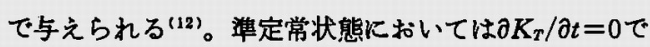
あるから，

$$
\begin{aligned}
V_{\mathbf{a}} & =\frac{\int \eta(j \cdot \boldsymbol{B}) d V}{\Phi_{z}} \\
& =\frac{2 \pi R\langle\eta(j \cdot \boldsymbol{B})\rangle_{V}}{\left\langle\boldsymbol{B}_{z}\right\rangle_{V}}=\frac{2 \pi R}{\pi a^{2}} \eta_{0} \zeta I_{p}
\end{aligned}
$$

となる。ただし，

$$
\zeta \equiv \frac{\langle\eta(\boldsymbol{j} \cdot \boldsymbol{B})\rangle_{\boldsymbol{V}}}{\eta_{0}\left\langle\boldsymbol{j}_{\mathbf{z}}\right\rangle_{V}\left\langle\boldsymbol{B}_{\boldsymbol{z}}\right\rangle_{\boldsymbol{V}}} \sim 10
$$

である。らは $\eta, \boldsymbol{j}, \boldsymbol{B}$ の空間分布で決まる無次元数で, 標準的な变形されたへッセル関数モデルで計算する

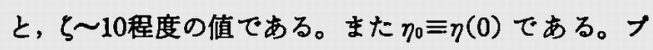
ラズマ周辺の磁場の乱れにより，砅が壁を切る場 合は表面からの寄与のためにらの值は增加する。トカ マクの場合は $\zeta=j_{z}(0) /\left\langle J_{s}\right\rangle_{V} \sim 3$ 程度である。( 6 )式 を(4)式に代入すると

$$
\tau_{z}=\frac{3}{16}\left(\frac{\mu_{0} a^{2}}{\eta_{0}}\right) \frac{\beta_{\theta}}{\zeta}
$$

が得られる。ブラズ、電流と龟子密度n。との間には 実験的仡

$$
\frac{I_{p}}{\pi a^{2}\left\langle n_{e}\right\rangle_{V}}=(1 \sim 10) \times 10^{-14} \mathrm{~A} \cdot \mathrm{m}
$$

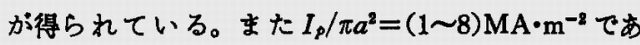
る。 $I_{p}<0.5 \mathrm{MA}$ のれまでの実験結果では, $\beta_{\theta} \sim 0.1$ の值が得られており，Ipの增加とともにやや減少傾向 す見えるが，その依存性は小さい。RFX(第 7 图)， ZT-H(第 8 図)によって $I_{p} \sim 2 \mathrm{MA}$ の範团の実験データ が得られるであろう。RFPのエネルギー損失機構につ いては種々調べられているが(13) (15)，トカマク以上に 不確定なのか現状である。第 1 表に主なRFP装固のハ ラメータを示す。ウィスコンシン大学のMST(Madison Symmetric Torus) が実験データを出し始めた。近い 将来運転を始める RFX,ZT-Hのハランメータは実験的 比例則から予測した值である。

\section{ท. RFPにおけるイオンの異常加熱}

RFPのイオン温度T、湘定すると，いくつかの装置 (例えば ZT-40 M, HBTX-1 B, REPUTE-1, TPE-IRM 15,ETA-BETA等)で，実験条件によっては電子温度 $T$ 。と同程度かそそれよりかなり高いことが観測され

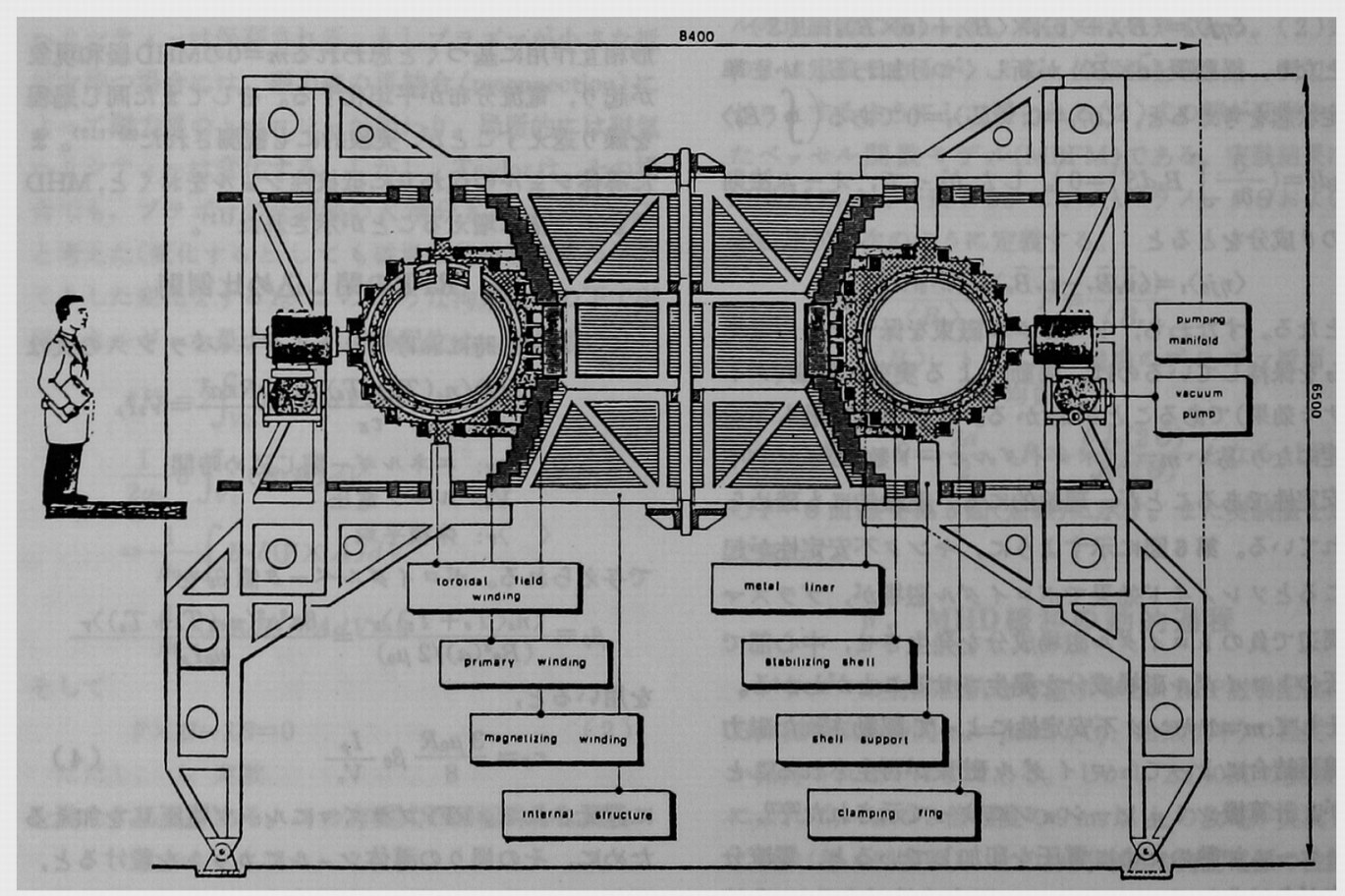

第 7 图 RFX装置の断面図 


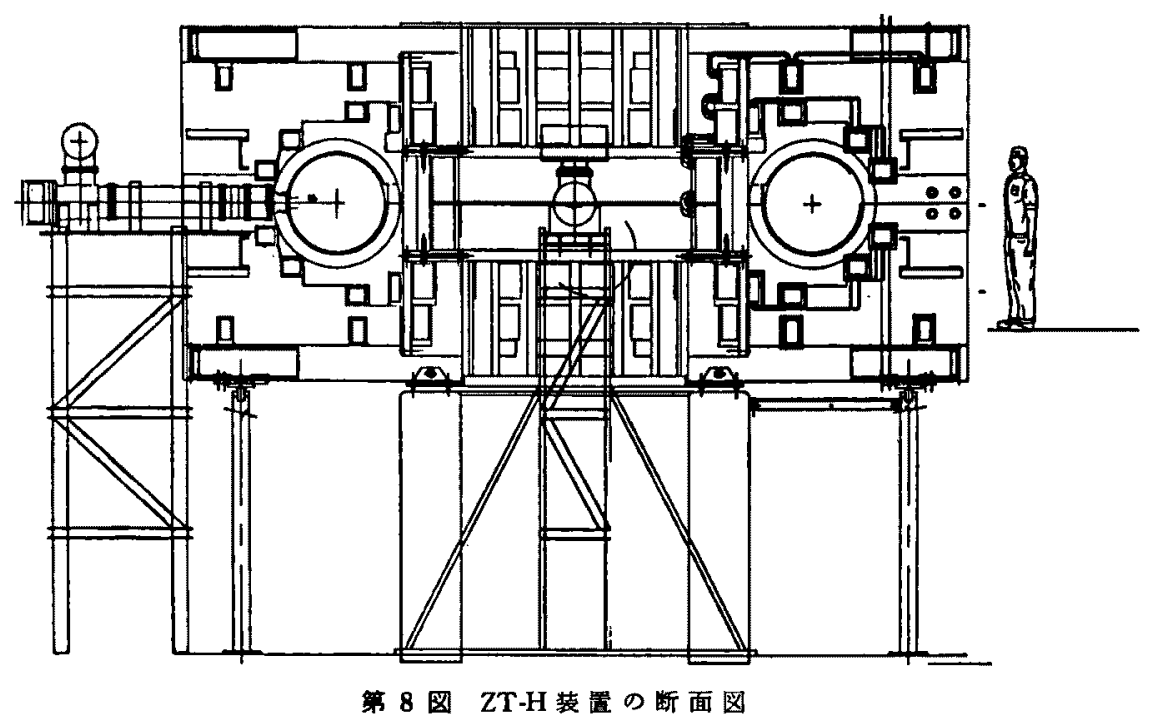

第 1 表 RFP装置のバラメータ

\begin{tabular}{lllllllll}
\hline 装置 & 研究所 & $R(\mathrm{~m})$ & $a(\mathrm{~m})$ & $I_{p}(\mathrm{MA})$ & $\bar{n}_{20}$ & $T_{e 0}(\mathrm{keV})$ & $\tau_{E}(\mathrm{~ms})$ & $\beta_{\theta}$ \\
\hline ZETA & Harwell & 1.5 & 0.48 & $0.4 \sim 0.7$ & 0.5 & 0.18 & 0.3 & 0.1 \\
HBTX 1 B & Culham & 0.8 & 0.26 & 0.43 & $0.3 \sim 0.5$ & 0.5 & 0.5 & $0.1 \sim 0.2$ \\
ETA-BETA & Padova & 0.65 & 0.125 & 0.2 & $0.5 \sim 1$ & 0.2 & 0.1 & 0.1 \\
ZT-40 M & Los Alamos & 1.14 & 0.2 & 0.4 & 0.8 & $0.1 \sim 0.5$ & 0.7 & 0.1 \\
OHTE & GA Tech & 1.24 & 0.19 & 0.5 & 4.0 & 0.5 & 0.3 & $0.1 \sim 0.2$ \\
TPE-1 RM 15 & 電紛研 & 0.7 & 0.15 & 0.14 & $0.2 \sim 0.3$ & 0.6 & 0.2 & 0.1 \\
STP-3 M & 名 大 & 0.5 & 0.09 & 0.2 & 0.5 & 0.3 & 0.1 & 0.1 \\
REPUTE-1 & 東 大 & 0.82 & 0.2 & 0.3 & 0.6 & 0.13 & 0.07 & 0.08 \\
MST & Wisconsin & 1.5 & 0.5 & 0.55 & 0.1 & $\sim 0.4$ & $\sim 1$ & 0.1 \\
RFX ${ }^{\dagger}$ & Padova & 2.0 & 0.475 & $2.0^{*}$ & $1.0^{*}$ & $2^{*}$ & $13 \sim 25^{*}$ & $0.1^{*}$ \\
ZT-H $\dagger \dagger$ & Los Alamos & 2.4 & 0.4 & $2.0^{*}$ & $1.2^{*}$ & $2^{*}$ & $\sim 20^{*}$ & $0.1^{*}$ \\
\hline
\end{tabular}

n20: $10^{20} \mathrm{~m}^{-3}$ 単位の电子密度，RFX，ZT-Hのパラメータは予想值*

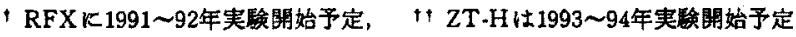

た。これらの饻監においては，イオンのニネルギー閉 じ込め時間は，電子・イオン間のニネルギー緩和時間 より短いため，オーム加熱された電子との衡突による イオン加熱の可能性はない。したがって，イオンの直 接加熱檴構が存在することが明らかになってきた。こ ネルギー保存則は

$$
I_{\rho} V=\frac{\partial}{\partial t} \int \frac{B^{2}}{2 \mu_{0}} d V+\int E \cdot j d V
$$

となる。オームの法則を( 9 )式右辺第 2 項化代入する 之.

$$
E \cdot j=\eta j^{2}+(j \times B) \cdot v
$$

となり，(10)式右辺第 2 項はMHDの運動方程式より

$$
\begin{aligned}
(j \times B) \cdot v= & \frac{\partial}{\partial t}\left(\frac{\rho_{m} v^{2}}{2}+\frac{3}{2} p\right) \\
& +V \cdot\left[\left(\frac{\rho_{m} v^{2}}{2}+\frac{3}{2} p+p+\Pi\right) \cdot v\right] \\
& -\sum_{i j} \Pi_{t s} \frac{\partial v_{t}}{\partial x_{j}}
\end{aligned}
$$

が得られる。 $\rho_{\mathrm{m}}$ は筫量密度，pは压力， $I$ は非等方性 圧力成分テンサーであり，粘性項に対応する。(10)式 右辺の第 1 項はオーム加熱項で電子加熱に奇与する が，(10)式右刃の第 2 項の加速項はイオンの加熱に奇 与すると考えることができる。磁気摇䖝のエネルギー

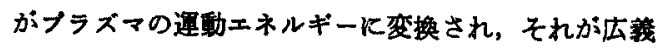
の粘性加熟によってイオン加熱するといらシナリオが 
最す可能性のある候補である(18)。したがって，磁気 播動が少ない状態ではイオンの異常加熱は弱くなり, 閉し込めのよい状態とイオン異常加熱とは両立しない ことが予湘される。

\section{ท. RFPの研究課題と展望}

RFPブラズマのこれからの課題は, 高温领域のェネ ルギー閉し还め比例則, 不純物制御, ブラズマ電流駆動 である。近い将来, 運転に入るRFX, ZT-Hは,トカマ クのPLT, T-10k対応すると考えられる装監であり， 不純物制御, 電流駆動の本格的研究はこれから始まる といってむよい。

\section{1. 不耗物制街}

トカマクで用いられたグロ一放電洗浄, 放䉓内側 のカーボン・タイル張り等で低 $Z$, 高 $Z$ 不純物の低隇効 果は観測されている。ポンプリミター,ダイハータに よる不純物制御の研究はこれからの課題である。トカ マクで成功しているボロイダル・ダイバータをRFP 適用する場合, RFPブラズマ境界では $\left|B_{\theta}\right|>\left|B_{x}\right|$ であ ろからブラズマからダイバータフレートまでの磁力 線に沿与路離が短く、この効果についての检討が必要 となろら。トロイダル・ダイバータ考えられている が，回転対称性を失ら不利な点む評価する必要があ る。

\section{2. 党流臤}

低域混成波あるいは高速中性粒子ビーム入射に上る ブラズマ電流駆動はRFPKも適用できるが，高速電子 あるいは高速イオンの閉じ込め時間が上く，その減速 時間より長くないと効率が落ちることはいらまであな い。またRFP特有の MHD綬和を利用した振動場電流 駆動法(OFCD; Oscillating Field Current Drive) b くはF- パンピングが提案されている(12)。そして予借 実験も行われた(17)。これ性磁気へリシティーバラン スの (5) 式の右边第 2 項の $V_{s}$ よび $\Phi_{s}$ を

$$
V_{z}(t)=\tilde{V}_{z} \cos \omega t, \quad \Phi_{s}(t)=\Phi_{s 0}+\tilde{\Phi}_{x} \cos \omega t
$$

之変化させて, 両者の䅡の直流成分によって, 抵抗損 失の右辺第 1 項を補ら方法である。その駆動効率, 振
動場を加えることによるブラズマへの摄乱奻果の評 価，技術的問題等，多くの課題が控えている。

\section{3. 高温領域におけるエネルギー閉じ込め}

現在の実験領域と於心ブラズマ領城とは大きな隔た りがあり，RFP炉を展望しようとすると、どうしても 憶測的な要素が入ってしまら。したがってここでは， あるRFP炉を想定したとき，どのよらな閉し込め比例 則が必要になるかといら立場で述べるRFP师につい ては既にいくつか発表されており，第2 表炕それらの 主なパラメータを示す。基本バラメータとしてブラス 、半径 $a$,ブラズマ電流 $I_{p}$, ブラズマの温度 $\langle T\rangle\left(T_{t}=\right.$ $T$ 。を仮定)，密度〈 $n\rangle$ を選ぶ。たたし（〉は体積平均 を表わす。簡単のため $T=2\langle T\rangle\left(1-\rho^{2}\right), n=1.5\langle n\rangle(1$ $\left.-\rho^{4}\right),(\rho=r / a)$ 分布を仮定すると，

$$
\begin{aligned}
\beta_{\theta} & =2\langle n T\rangle /\left(B_{\theta}{ }^{2} / 2 \mu_{0}\right) \\
& =0.1\left\langle n_{20} \times T\right\rangle_{\mathrm{kav}} / B_{\theta}{ }^{2}(T)
\end{aligned}
$$

となり，中性子壁負荷 $W_{n}$ は核融合反応率を $\overline{\sigma v} \propto\langle T\rangle^{2}$ 之近似して $W_{n}=7.2 \times 10^{-3}\left\langle n_{20}\right\rangle^{2}\langle T\rangle^{2}{ }_{10} v a \mathrm{MW} / \mathrm{m}^{2}$, 全 核融合出力住 $P_{N P}=(17.58 / 14.67) W_{n} 2 \pi a 2 \pi R$ として 第 2 表に示した $\left(n_{20}\right.$ は $10^{20} \mathrm{~m}^{-3}$ 単位の密度)。また $j_{1} \equiv$ $I_{p} / \pi a^{2}, I_{p} / N \equiv I_{p} /\left(\pi a^{2}\langle n\rangle\right)$ b付け加克た。第 1 表の 現存ブラズマのパラメータと比較して気ががりなの は，想定べータ値が $\beta_{\ominus} \sim 0.2$ と高いことである。

そこで，次のような比例則を設定して外㨉しな時に どうなるかを考察する。

$$
\left.\begin{array}{l}
\beta_{\theta}=0.1 \\
T_{0}(\mathrm{keV})=I_{p}(\mathrm{MA})
\end{array}\right\}
$$

オーム加熱開し这め時間の(7)式とSpitzer 抵抗の式 $\eta_{0}=3.3 \times 10^{-8} \times Z_{\text {ort }} / T_{0}{ }^{1.5}\left(\eta_{0}=\Omega-\mathrm{m}\right.$, 中心温度 $T_{0}$ 生 $\mathrm{keV}$ 単位) と $\beta_{\theta}$ の定義を用いると，

$$
\begin{aligned}
& \tau_{E}=7.1 \frac{\beta_{\theta} a^{2} T_{0}{ }^{1.5}}{\zeta Z_{\text {ort }}} \\
& \left\langle n_{20} T\right\rangle \tau_{B}=\frac{3.5}{\zeta Z_{o t t}} \beta_{\theta}^{2} I_{p}^{2} T_{0}^{1.5}
\end{aligned}
$$

\begin{tabular}{|c|c|c|c|c|c|c|c|c|c|c|c|c|}
\hline & $\begin{array}{c}a \\
(m)\end{array}$ & $\begin{array}{c}I_{p} \\
(\mathrm{MA})\end{array}$ & $\begin{array}{c}\langle T\rangle \\
(\mathrm{keV})\end{array}$ & $\begin{array}{c}\left\langle n_{20}\right\rangle \\
\left(10^{20} \mathrm{~m}^{-3}\right)\end{array}$ & $\begin{array}{c}R \\
(\mathrm{~m})\end{array}$ & $\begin{array}{c}j_{*} \\
\left(\mathrm{MA} / \mathrm{m}^{2}\right)\end{array}$ & $\begin{array}{c}I_{p} / N \\
\left(10^{-16} \mathrm{~A} \cdot \mathrm{m}\right)\end{array}$ & $\beta_{\theta}$ & $\begin{array}{c}B_{\theta}(a) \\
(\mathrm{T})\end{array}$ & $\begin{array}{c}W_{n} \\
\left(\mathrm{MW} / \mathrm{m}^{2}\right)\end{array}$ & $\begin{array}{c}P_{N F} \\
(\mathrm{GW})\end{array}$ & 龦 考 \\
\hline Culham ${ }^{(18)}$ & 1.5 & 17.0 & 10 & 1.34 & 14.5 & 2.4 & 1.8 & 0.26 & 2.3 & 1.9 & 2.0 & 標濩炻 \\
\hline CRFPR $^{(19)}$ & 0.71 & 18.4 & 10 & 6.6 & 3.8 & 11.6 & 1.8 & 0.24 & 5.2 & 22 & 2.8 & コンパクト炡 \\
\hline TITAN $^{(20)}$ & 0.6 & 17.8 & 10 & 7.0 & 3.9 & 15.7 & 2.2 & 0.2 & 5.9 & 21 & 2.3 & コンパクト炉 \\
\hline REPUTER $^{(21)}$ & 1.6 & 23.0 & 11 & 1.8 & 9.8 & 2.9 & 1.6 & 0.24 & 2.9 & 4.5 & 3.3 & 標準炉 \\
\hline
\end{tabular}

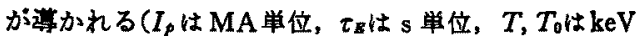
単位)。

フラズマ半径 $a=1.0 \mathrm{~m}$ (C炉), $a=1.6 \mathrm{~m}(\mathrm{~S}$ 炉)の 2

第 2 表 RFP秙の設計バラメータ 
例をとり， $=10, Z_{\text {otr }}=2$ とし, $I_{p}=20 \mathrm{MA}$ とて 2 例 のバラメータを計算した值を第 3 表に示す。 $\beta_{\theta}=0.24$ $\rightarrow 0.1$ K設定したことにより，密度 $n$ の做が小さくな っている。また次の比例則を想定した场合について， 同様な結果を第 4 表に示す。

$$
\left.\begin{array}{l}
\beta_{\theta}=0.1 \\
T_{\theta}(\mathrm{keV})=0.5\left[2 I_{p}(\mathrm{MA})\right]^{0 . \theta}
\end{array}\right\}
$$

第 2 表の例は $\beta_{\theta} \sim 0.24, T_{0}(\mathrm{keV}) \sim I_{p}(\mathrm{MA})$ の比例則を 想定していると見なすことすできる。比例則がよりき びしくなる場合は，必要なブラズ、電流が大きくな る。場合によっては，オーム加熱外の追加熱が必要に なるかる知れない。このように高温領域における閉じ 込め比例則は，RFP庐の設計パラメータに大きな影警 を与えるので, その改善は重要な課題である。

\begin{tabular}{|c|c|c|c|c|c|c|c|c|c|c|c|}
\hline & $\stackrel{a}{(m)}$ & $\begin{array}{c}I_{p} \\
\text { (MA) }\end{array}$ & $\begin{array}{c}\langle T\rangle \\
(\mathrm{keV})\end{array}$ & $\begin{array}{l}\tau_{E} \\
(\mathrm{~s})\end{array}$ & $\begin{array}{c}\left\langle n_{20}\right\rangle \\
\left(10^{20} \mathrm{~m}^{-3}\right)\end{array}$ & $\begin{array}{c}\left\langle n_{20}\right\rangle \tau_{E} \\
\left(10^{20} \mathrm{~m}^{-\mathrm{a}} \cdot \mathrm{s}\right)\end{array}$ & $\beta_{\theta}$ & $\begin{array}{c}j \\
\left(\mathrm{MA} / \mathrm{m}^{2}\right)\end{array}$ & $\begin{array}{c}I_{p} / N \\
\left(10^{-14} \mathrm{~A} \cdot \mathrm{m}\right)\end{array}$ & $\begin{array}{c}B_{\theta}(a) \\
(\mathrm{T})\end{array}$ & $\begin{array}{c}W_{n} \\
\left(\mathrm{MW} / \mathrm{m}^{2}\right)\end{array}$ \\
\hline C 柾 & 1.0 & 20 & 10 & 3.2 & 1.6 & 5.1 & 0.1 & 6.4 & 4.0 & 4 & 1.8 \\
\hline S悟 & 1.6 & 20 & 10 & 8.1 & 0.63 & 5.1 & 0.1 & 2.5 & 4.0 & 2.5 & 0.45 \\
\hline
\end{tabular}

第 3 表 (12)式のもデルによるRFP炑のパラメータ

第 4 表（15）式のモデルルよるRFP师のパラメータ

\begin{tabular}{cccccccccccc}
\hline & $\begin{array}{c}a \\
(\mathrm{~m})\end{array}$ & $\begin{array}{c}I_{p} \\
(\mathrm{MA})\end{array}$ & $\begin{array}{c}\langle T\rangle \\
(\mathrm{keV})\end{array}$ & $\begin{array}{c}\tau_{E} \\
(\mathrm{~s})\end{array}$ & $\begin{array}{c}\left\langle n_{20}\right\rangle \\
\left(10^{20} \mathrm{~m}^{-3}\right)\end{array}$ & $\begin{array}{c}\left\langle n_{20}\right\rangle \tau_{E} \\
\left(10^{20} \mathrm{~m}^{-3} \cdot \mathrm{s}\right)\end{array}$ & $\beta_{\theta}$ & $\begin{array}{c}j_{*} \\
\left(\mathrm{MA} / \mathrm{m}^{2}\right)\end{array}$ & $\begin{array}{c}I_{p} / N \\
\left(10^{-14} \mathrm{~A} \cdot \mathrm{m}\right)\end{array}$ & $\begin{array}{c}B_{\theta}(a) \\
(\mathrm{T})\end{array}$ & $\begin{array}{c}W_{n} \\
\left(\mathrm{MW} / \mathrm{m}^{2}\right)\end{array}$ \\
\hline $\mathrm{C}^{\prime}$ 将 & 1.0 & 30 & 10 & 3.2 & 3.6 & 11.5 & 0.1 & 9.6 & 2.7 & 6 & 9.3 \\
$\mathrm{~S}^{\prime}$ 帅 & 1.6 & 30 & 10 & 8.1 & 1.4 & 11.5 & 0.1 & 3.75 & 2.7 & 3.8 & 2.3 \\
\hline
\end{tabular}

\section{VI. 桔 語}

RFX,ZT-Hの計画が近い将来, 実驗段跸に進み, IEA 萃下で日米欧RFP国際協力協定が調印されたこの機会 KRFPの現状を振り返りそその展望を試みた。これか らの研究の進展が期待される。

\section{一考文献一}

(1) Bodin, H.A.B., Newton, A.A.: Nucl. Fusion, 20, 1255 (1980)

(2) Robinson, D.C., KIng, R.E.: Plasma Phys. Controll. Nucl. Fusion Res. (Conf. Proc. Novosibirsk, 1968), Vol. 1, p. 17 (1969), IAEA.

(3) BodiN, H.A.B.: Invited paper at Symp. New Trends in Unconventional Approaches to Magnetic Fusion, Stockholm June 1982.

(4) TAYLOR, J.B.: Phys. Rev. Lett., 33, 1139 (1974).

(5) BAKer D.A., et al.: Plasma Phys. Control. Nucl. Fusion Res. (Conf. Proc. Baltimore 1982), Vol. 1, p. 587 (1983), IAEA.

(6) Schnack, D.P., Caramana, E.J., Nebel, R.A.: Phys. Fluids, 28, 321 (1985).

(7) Kusano, K., SATo, T.: Nucl. Fusion, 26, 1051 (1986); 27, 821 (1987).

(8) UEDA, Y., et al.; Nucl. Fusion, 27, 1453 (1987).

(9) Asakura, N., Nagayama Y., Shinohara S., ToYAMA, H., MIYAMOTO, K.: ibid., 29, 893 (1989).
(10) Miүамото, K.: Plasma Phys. Controll. Fusion, 30, 1493 (1988).

(1) Gimblett, C.G.: Nucl. Fusion, 26, 617 (1986).

(14) Bevir, M.K., Gray, J.W.: Proc. Reversed Field Pinch Theory Workshop (LANL, Los Alamos 1981), Rep. No. 8944 C p. 176; BEviR, M.K., GIMBLETT, C.G.: Phys. Fluids, 28, 1826 (1985).

(13) Rechester, A.B., Robendluth, M.N.: Phys. Rev. Lett., 40, 38 (1978).

(14) JI, H., et al.: Submitted to Phys. Rev. Lett.

(15) INGRAhaM, J.C., Ellis, R.F., DOWNING, J.N., Munson, C.P., Weber, P.G., Wurden, G.A.: Phys. Fluids, B 2, 143 (1990).

(16) MIYAмото, K., et al.: To be published in Plasma Phys. Controll. Nucl. Fusion Res. (Conf. Proc., Washington D.C. 1990), CN-53 C-2-4 (1991), IAEA.

(i) Schoenderg, K.F., et al.: Phys. Fluids, 31, 2285 (1988).

(19) Hancox, R., Walters, C.R.: Plasma Phys. Controll. Nucl. Fusion Res. (Conf. Proc. Innsburg 1978), Vol. 3, 323 (1979), IAEA.

(dd) Hagenson, R.L., Krakowski, R.A., Bathke, C. G., Miller, R.L.: ibid. (Conf. Proc., Lond on 1984), Vol. 3, 373 (1985).

bo) Conn, R.W., Najmabadi, F, KRakowski, R.A. Schultz, K.R., Steiner, D.: ibid. (Conf. Prac., Nice 1988), Vol. 3, 315 (1989).

(21) 近藤駿介編: UTNL-R-0163，(1984), 